\title{
Carbon dioxide as a substitute for iodine contrast in arteriography during embolectomy
}

\author{
Uso de dióxido de carbono como substituto ao contraste iodado em arteriografia durante embolectomia
}

\author{
Nelson Wolosker ${ }^{1}$, Marcelo Passos Teivelis ${ }^{1}$, Cynthia de Almeida Mendes ${ }^{1}$, \\ Kenji Nishinari ${ }^{1}$, Mariângela de Freitas Ribeiro ${ }^{1}$, Sergio Kuzniec ${ }^{1}$
}

\begin{abstract}
Acute limb ischemia can be potentially harmful to the limb and life threatening. Renal failure is a possible outcome associated with release of products of ischemic limb reperfusion. Some authors reported the benefit of performing angiography after embolectomy, even though iodine contrast is also nephrotoxic. We report a case of embolectomy on a patient with renal insufficiency in whom carbon dioxide was used as a substitute for iodine contrast.
\end{abstract}

Keywords: Renal insufficiency, chronic; Embolism; Angiography; Carbon dioxide; Reperfusion injury; Case reports

\section{RESUMO}

A isquemia aguda de membro pode ser danosa para o membro e para a vida. A insuficiência renal é um desfecho possível associado à liberação dos produtos da reperfusão do membro isquêmico. Alguns autores relatam o benefício de realização de angiografia após embolectomia, apesar do contraste iodado também ser nefrotóxico. Relatamos um caso de embolectomia em uma paciente com insuficiência renal, em que o dióxido de carbono foi utilizado como substituto para o contraste iodado.

Descritores: Insuficiência renal crônica; Embolia; Angiografia; Dióxido de carbono; Traumatismo por reperfusão; Relatos de casos

\section{INTRODUCTION}

Acute embolic limb ischemia is an urgent clinical condition in which sudden decrease or worsening in limb perfusion causes a potential threat to extremity viability and to life.
Treatment consists of prompt revascularization with an embolectomy catheter. Thorough removal of all occlusive emboli in the arterial tree results in the best outcomes; hence, some authors favored arteriography after embolectomy for lower limbs. ${ }^{(1)}$

Angiography is traditionally performed with iodinated contrast material, but carbon dioxide $\left(\mathrm{CO}_{2}\right)$ has been studied as an alternative intravascular contrast agent ${ }^{(2)}$ for patients with iodine allergy or renal function impairment. Since it is not nephrotoxic, it was considered reasonable to utilize this contrast in a patient with borderline renal function who would be submitted to the noxious stimuli of the reperfused limb after revascularization. ${ }^{(3)}$

To the best of our knowledge, this was the first case assessing the intraoperative use of $\mathrm{CO}_{2}$ as a substitute for iodine contrast in a patient with known chronic kidney disease and an acute ischemic limb.

\section{CASE REPORT}

A 79-year-old woman presented to the emergency department with acute limb ischemia in her left leg with a 2-hour history. Past medical history was positive for hypertension, atrial fibrillation and non-dialysisdependent chronic renal failure.

Two years before, she had been operated on for acute aortic embolic occlusion, with bilateral femoral catheter embolectomy. She started oral anticoagulation (warfarin) after this episode. Upon discharge she presented pedal pulses, but no posterior tibial pulses on either limb.

\footnotetext{
${ }^{1}$ Hospital Israelita Albert Einstein, São Paulo, SP, Brazil.

Corresponding author: Marcelo Passos Teivelis - Avenida Morumbi, 627, bloco A1, consultório 423 - Morumbi - Zip code 05652-000 - São Paulo, SP, Brazil - Phone: (55 11) 2151-5423 E-mail:dr.marcelo@consultoriovasculares.med.br

Received on: Oct 8, 2013 - Accepted on: Dec 6, 2013

DOI: 10.1590/\$1679-45082015RC2997
} 
Medication use was irregular, and her international normalized ratio (INR) of prothrombin time upon admission was 1.1. Her pulse was arrhythmic; she was hypertensive $(160 \times 110 \mathrm{mmHg})$ and presented with normal femoral, popliteal and pedal pulses on her right leg. On palpation in the left lower limb only a weak femoral pulse was observed; there were no distal pulses. The patient had pain and motor deficit. She was classified as grade IIb limb ischemia (immediately threatened) and was immediately referred for surgery.

Preoperative exams revealed a diminished creatinine clearance (Cockroft-Gault of $12 \mathrm{~mL} / \mathrm{min}$ ). General anesthesia was undertaken. Femoral access was performed on the scar tissue of the previous left femoral incision. Common, superficial and deep femoral arteries were dissected and clamped. Arteriotomy was performed and a 4-Fr embolectomy catheter was utilized (Edwards Lifesciences Corp, Irvine, California, USA). Thrombi were retrieved from both deep and superficial femoral arteries. The catheter progressed more than $60 \mathrm{~cm}$ on the superficial artery, but could not be felt neither on pedal artery topography nor on posterior tibial artery topography. Back bleeding was not significant, and a decision was made to perform an angiography to better assess the infra-popliteal arterial tree. $\mathrm{CO}_{2}$ was chosen as a substitute for iodine contrast for the angiography.

A homemade water seal $\mathrm{CO}_{2}$ delivery system was used, similar to another previously described, ${ }^{(4)}$ but with one modification to prevent room-air contamination. ${ }^{(5)}$ Injection was performed through a KMP 4Fr catheter (Cook, Inc. Bloomington, Indianopolis, USA) inserted in the arteriotomy while the arteries were clamped.

Figure 1 shows a patent popliteal artery, a patent fibular artery and an occlusion on the mid-third of the anterior tibial artery. We hypothesized that the embolectomy catheter reached the fibular artery on the first attempt, and thus could not be felt on physical exam.

A new embolectomy was then performed. The catheter progressed to the foot, on the topography of the pedal artery (i.e., the catheter could be felt on the projection of the artery), and more thrombi were retrieved. Control angiography (Figure 2) showed complete resolution of the anterior tibial artery occlusion, with contrast up to the foot (Figure 3). A total of $28 \mathrm{~mL}^{\circ} \mathrm{CO}_{2}$ was used, and no iodine contrast was needed.

Arteriorraphy was performed. The arteries were unclamped, and the popliteal and pedal pulses were noted to be present on the limb. Ischemia signs (e.g., pallor, hypothermia) were promptly resolved after arterial flow release. No compartment syndrome signs developed.

The patient remained in the intensive care unit (ICU) until the $11^{\text {th }}$ postoperative day. During this

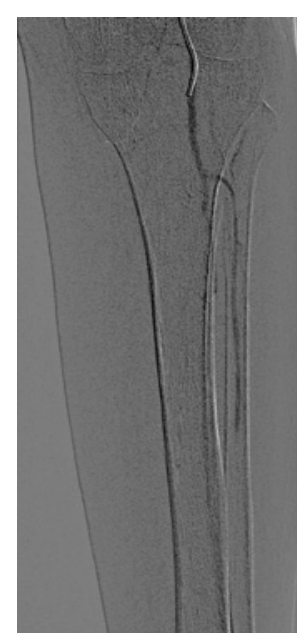

Figure 1. Carbon dioxide arteriography. Patent popliteal and fibular arteries, occlusion in the mid-third of the anterior tibial artery

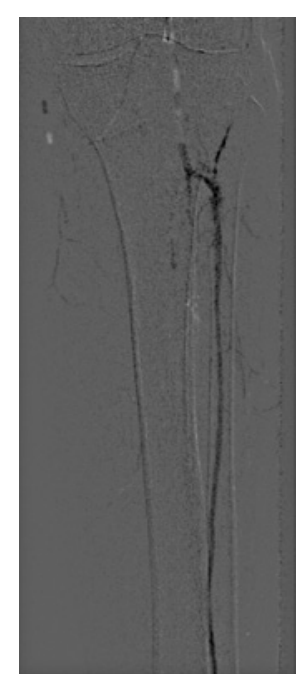

Figure 2. Carbon dioxide arteriography. Complete resolution of the anterior tibial artery occlusion

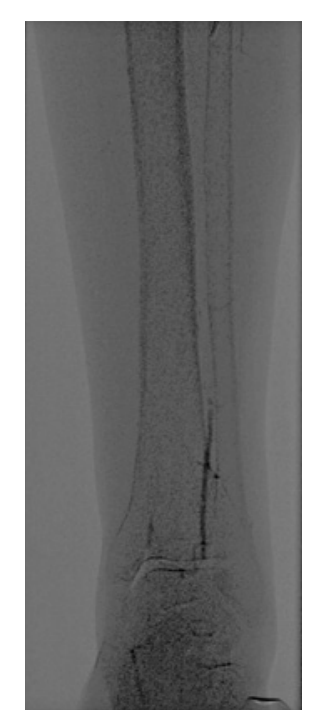

Figure 3. Carbon dioxide arteriography. Anterior tibial artery contrast perfusion to the foot 
period, the patient did not receive any nephrotoxic agent, such as vancomycin or vasoactive drugs. She maintained diuresis stimulated by furosemide. After ICU discharge she developed a urinary tract infection, as well as deteriorating renal function and uremia. Dialysis was started on the $18^{\text {th }}$ postoperative day. The patient developed pneumonia, which progressed to septic shock on the $36^{\text {th }}$ day of her admission. She required vasoactive drugs for 2 days at the ICU and, unfortunately, her renal function was never fully recovered. She was discharged from hospital to a hospice care facility with a pedal pulse and no deficit on her limb, though requiring chronic dialysis.

\section{DISCUSSION}

Treatment of embolic arterial occlusion with severe limb ischemia is well defined and involves the use of an embolectomy catheter as the best alternative. ${ }^{(6)}$

$\mathrm{CO}_{2}$ has been used electively in both diagnostic ${ }^{(7)}$ and therapeutic ${ }^{(8)}$ procedures in the femoropopliteal tree, and is reported to be safe ${ }^{(9)}$ and non-nephrotoxic. ${ }^{(10)}$

Intraoperative angiography was beneficial because it allowed the diagnosis of the arterial tree occlusion after the initial embolectomy. Additional removal of clots was performed and the result was documented as complete patency of the anterior tibial artery to the foot.

Our goal, when using $\mathrm{CO}_{2}$, was to decrease the need for postoperative dialysis. Probably, in this case, the deleterious stimuli (surgical stress, urinary tract infection and septic shock due to pneumonia) contributed to renal failure and subsequent need for dialysis. The countermeasure (such as the use of non-nephrotoxic contrast) could have prevented renal failure if it were a single condition. If we had used the iodinated medium, we might wonder if something could have been done differently to avoid dialysis.
We consider $\mathrm{CO}_{2}$ to be an alternative to iodine contrast when the decision to perform angiography is made in the acutely ischemic limb. To the best of our knowledge, this agent has never been described in this clinical setting; it presents good quality imaging, is not nephrotoxic and does not increase the risk for the limb or the patient in acute arterial occlusions. This approach may prove to be fruitful in patients with borderline renal function, thereby reducing the risk of short or long-term need for dialysis.

\section{REFERENCES}

1. Zaraca F, Stringari C, Ebner JA, Ebner $H$. Routine versus selective use of intraoperative angiography during thromboembolectomy for acute lower limb ischemia: analysis of outcomes. Ann Vasc Surg. 2010;24(5):621-7.

2. Patel BN, Kapoor BS, Borghei P, Shah NA, Lockhart ME. Carbon dioxide as an intravascular imaging agent: review. Curr Probl Diagn Radiol. 2011;40(5):208-17. Review.

3. Eliason JL, Wakefield TW. Metabolic consequences of acute limb ischemia and their clinical implications. Semin Vasc Surg. 2009;22(1):29-33. Review.

4. Kawasaki D, Fujii K, Fukunaga M, Masutani M, Nakata A, Masuyama T. Safety and efficacy of endovascular therapy with a simple homemade carbon dioxide delivery system in patients with ileofemoral artery diseases. Circ J. 2012;76(7):1722-8.

5. Mendes Cde A, Wolosker N, Krutman M. A simple homemade carbon dioxide delivery system for endovascular procedures in the iliofemoral arteries. Circ J. 2013;77(3):831.

6. Wolosker N, Kuzniec S, Gaudêncio A, Salles LR, Rosoky R, Aun R, et al. Arteria embolectomy in lower limbs. Sao Paulo Med J. 1996;114(4):1226-30.

7. Madhusudhan KS, Sharma S, Srivastava DN, Thulkar S, Mehta SN, Prasad G, et al. Comparison of intra-arterial digital subtraction angiography using carbon dioxide by "home made" delivery system and conventional iodinated contrast media in the evaluation of peripheral arterial occlusive disease of the lower limbs. J Med Imaging Radiat Oncol. 2009;53(1):40-9

8. Kessel DO, Robertson I, Patel J 5th, Peters K, Taylor EJ, Denton LJ, et al. Carbon-dioxide-guided vascular interventions: technique and pitfalls. Cardiovasc Intervent Radiol. 2002;25(6):476-83.

9. Moos JM, Ham SW, Han SM, Lew WK, Hua HT, Hood DB, et al. Safety of carbon dioxide digital subtraction angiography. Arch Surg. 2011;146(12):1428-32.

10. Hawkins IF Jr, Wilcox CS, Kerns SR, Sabatelli FW. CO2 digital angiography: a safer contrast agent for renal vascular imaging? Am J Kidney Dis. 1994;24(4):685-94. Review. 